\title{
Crack Pattern Analysis of Plain Concrete Pavement due to Swelling Pressure on Expansive Soil
}

\author{
Arif Afrianto $^{1, *}$, Ary Setyawan', Bambang Setiawan², Wibowo ${ }^{2}$ \\ ${ }^{1}$ Master Program in Civil Engineering, Universitas Sebelas Maret, Surakarta, 57126, Indonesia \\ ${ }^{2}$ Department of Civil Engineering, Faculty of Engineering, Universitas Sebelas Maret, Surakarta, 57126, Indonesia
}

Received September 21, 2021; Revised November 8, 2021; Accepted December 13, 2021

\begin{abstract}
Cite This Paper in the following Citation Styles
(a): [1] Arif Afrianto, Ary Setyawan, Bambang Setiawan, Wibowo, "Crack Pattern Analysis of Plain Concrete Pavement due to Swelling Pressure on Expansive Soil," Civil Engineering and Architecture, Vol. 10, No. 1, pp. 144 - 151, 2022. DOI: 10.13189/cea.2022.100113.
\end{abstract}

(b): Arif Afrianto, Ary Setyawan, Bambang Setiawan, Wibowo (2022). Crack Pattern Analysis of Plain Concrete Pavement due to Swelling Pressure on Expansive Soil. Civil Engineering and Architecture, 10(1), 144 - 151. DOI: 10.13189/cea.2022.100113.

Copyright $\odot 2022$ by authors, all rights reserved. Authors agree that this article remains permanently open access under the terms of the Creative Commons Attribution License 4.0 International License

\begin{abstract}
This research was conducted on the Surakarta-Gemolong-Geyer provincial road which is suspected to be built on expansive soil using the ATENA V5 3D software program. ATENA program can be used to simulate crack propagation in concrete and reinforced concrete structures. This study uses quantitative analysis methods, to the analysis of fracture patterns of rigid pavements with transverse reinforcement on expansive soils. Rigid pavement is modeled into 2 types, namely rigid transverse reinforced pavement models due to swelling pressure forces on expansive soils and transverse reinforced rigid pavements without swelling pressure forces on expansive soils. The swelling test on the soil carried out in the laboratory was $37 \mathrm{kPa}$. The rigid pavement model is subjected to load testing. The load used is the standard load of a medium-sized truck. The repetition of loading used is 30 times. The loading is divided into 3 types, namely: edge, center, and corner loading. The results of the analysis of rigid pavements were compared between rigid pavements due to swelling pressure forces on expansive soils with rigid pavements without swelling pressure forces. The results of the analysis from the ATENA software program show that every loading test on rigid pavement due to swelling pressure forces cracks greater than loading without swelling pressure forces. Edge loading shows that cracks due to swelling pressure are $3.5 \%$ higher than those without swelling pressure. Middle loading shows cracks due to swelling pressure which is $8.33 \%$ greater. Middle loading shows that cracks due to
\end{abstract}

swelling pressure are $3.56 \%$ higher than without swelling pressure. This research can be used as a reference and prediction in identifying cracks that occur so that the government can carry out appropriate design planning and maintenance and rehabilitation of rigid pavements on expansive soils.

Keywords Rigid Pavement, Swelling Pressure, Crack Pattern, ATENA 3D Software

\section{Introduction}

Transportation is one of the means of supporting national development. Along with the increasing human needs in various sectors, the problems that exist are also increasing, including transportation problems. Therefore, to overcome this transportation problem, adequate facilities and infrastructure are needed so that they can always support transportation optimally. One of the most important facilities and infrastructure in transportation is the highway. In Indonesia itself, which is a country with a large number of islands, roads are one of the infrastructures that have an important role so that the distribution of needs in each region can be reached. In this case, the road must be planned as well as possible, effectively and efficiently, so that the road is able to provide optimal services for the sustainability of 
transportation. The importance of the function of road infrastructure that can move the wheels of the economy, so with the development of the times, construction development continues. With the development of construction on road infrastructure can increase the level of comfort and safety of the road itself. This can be done by conducting research on the material that will be used as a constituent of the road. One of them is the concrete material used as a road pavement material (rigid pavement). Rigid pavement is a pavement in the form of a concrete slab with or without reinforcement on the subgrade with or without a lower foundation and traffic loads are transmitted to the concrete slab [1]. The failure of rigid pavement construction that occurs in expansionary soils is principally due to a limited understanding of the properties of the soil. This results in the analytical method used in determining treatment to be less relevant. The lack of understanding of planners and implementers on the behavior of pavement structures on expansive soils and the behavior of expansive soils, often causes the design approach and implementation method chosen to be less precise. Of course, this will result in the high cost of handling construction that must be applied, even some of the constructions that have been handled have failed a lot. A common problem in expansive soils is swelling or swelling in the soil. Swelling is an important parameter to understand the expansive properties of the soil [2].

Expansive soil has been recognized as a problem that can pose a threat to the stability of the earth's structure due to significant soil volumetric changes when subjected to moisture variations [3]. This type of soil will usually expand in the rainy season and shrink back in the dry season. This soil shrinkage is not evenly distributed between one point and another so that it can cause differential movement. This can also cause damage to the road construction on it. The crack pattern analysis will be used as concrete pavement damage caused by swelling pressure due to the different moisture content in expansive soil.

This study uses soil data input from swelling pressure obtained from laboratory tests which in several previous studies have never been done. Previous researchers only used soil CBR data in the form of assumptions or secondary data that had existed in previous studies that did not have accuracy or real values according to soil conditions in the field.

\section{Research Method}

Expansive subgrades cause a lot of damage problems on highway pavements, so that pavements located on expansive subgrades often require large maintenance and rehabilitation costs before the pavement reaches its design life [4]. Expansive soil is soil or rock whose clay content has the potential for shrinkage due to changes in water content, so that its carrying capacity is strongly influenced by changes in water content [5]. A common problem in expansive soils is swelling or swelling in the soil. Swelling is an important parameter to understand the expansive nature of the soil [6]. Soil will expand when the water content increases, for example in the rainy season, and shrink when dry in the dry season.

If in an area the type of soil is expansive soil, the type of pavement that is suitable to be built on it is rigid pavement [7]. In wet conditions (rainy season) the soil expands and becomes very soft (reduces soil shear strength) so that the soil experiences vertical and horizontal deformation and causes damage to the pavement above it. In dry conditions (dry season), the water in the soil will experience evaporation (evaporation) so that the soil will shrink, especially in the layer near the surface. This condition will also cause cracks and also cause damage to the pavement above it [8]. From the results of this research, the crack pattern analysis could be used as the awareness for concrete pavement design to include the swelling pressure in the calculation of thickness and reinforcement as well as to prevent preventive pavement damage so that the durable and sustainable concrete pavement could be achieved.

\section{Materials and Methods}

This study uses quantitative analysis methods to analyze the flexural behavior of rigid pavement slabs due to swelling on expansive soils and experimental methods to create structural models using the ATENA software tool. The location of this research is on the Surakarta-Gemolong-Geyer road as presented in Figure 1, because the road is suspected of containing expansive soil.

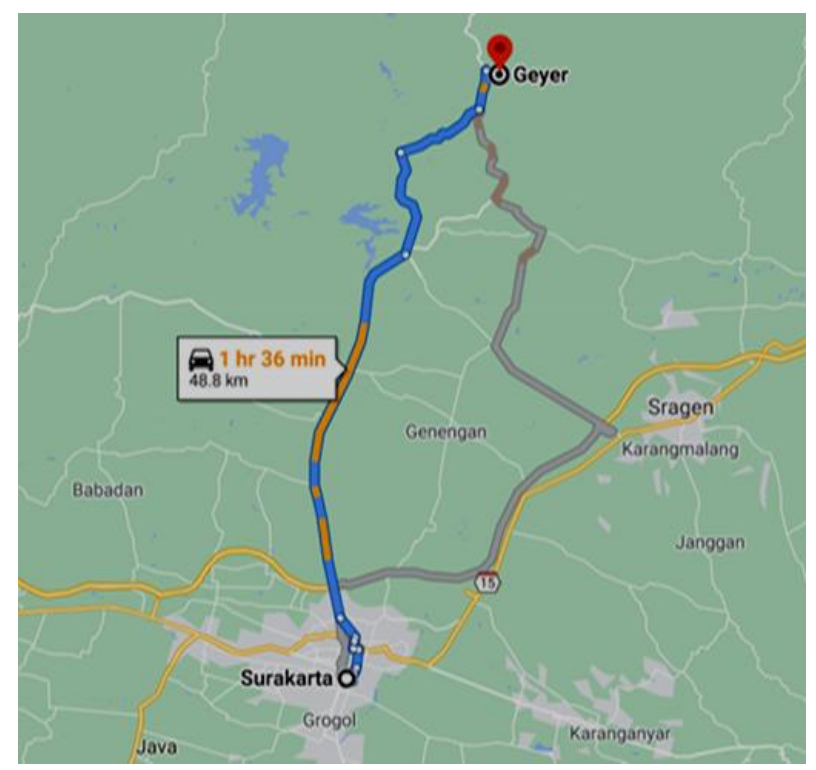

Figure 1. Research Site Map

This research requires the limitations of the problem, 
including:

1. The type of pavement used is continuous rigid pavement with the addition of transverse (existing) reinforcement.

2. The modeled soil is soil due to swelling pressure (soil expands).

3. The soil data used are soil from Geyer in the swelling pressure test in the soil mechanics laboratory.

Based on references from several studies that have been carried out, this study tries to combine and examine the two interrelated aspects, namely between expansive soil and rigid pavement above it. The swelling model below is based on the triangle method [11]

Soil samples in the area were then taken to be tested in the laboratory. The results of soil testing in the laboratory include soil properties test and swelling pressure test. The test data will later be used as input data for analysis with ATENA 3D software.

ATENA program can be used to simulate crack propagation in concrete and reinforced concrete structures by numerical models based on fracture mechanics [9]. Technological innovations have helped researchers to develop ways to identify crack patterns in rigid pavements. [10]

The rigid pavement data are taken from the data as built drawing of the Central Java Provincial Public Works Office in 2019. Below is presented the rigid pavement data used for analysis in the ATENA software, as presented in Table 1

Table 1. Rigid pavement data

\begin{tabular}{|c|c|}
\hline \multicolumn{2}{|c|}{ Data } \\
\hline Slab thickness & $25 \mathrm{~cm}$ \\
\hline Slab dimension & $6 \times 3.5 \mathrm{~m}$ \\
\hline Concrete quality & $\mathrm{K} 350$ \\
\hline Poisson's ratio & 0.16 \\
\hline Fc' & $29000 \mathrm{KN} / \mathrm{m}^{2}$ \\
\hline Reinforcement & Diameters $12 \mathrm{~mm}$ \\
\hline
\end{tabular}

The existing soil and rigid pavement data are then entered into the ATENA 3D software for further analysis of the deflection and crack patterns. The ATENA program can be used to calculate the deflection and describe the crack pattern that occurs in the pavement structure due to the load acting on the pavement. The general data required for the complete ATENA program input as presented in Table 2.
Table 2. General data analysis of the structure of the ATENA program

\begin{tabular}{|c|c|c|}
\hline No. & Information & ATENA Program \\
\hline \multirow{4}{*}{1.} & \multirow{3}{*}{ Input } & Pressure Test \\
\cline { 3 - 3 } & & Modulus Elasticc \\
\cline { 3 - 3 } & & Poisson's Ratio \\
\cline { 3 - 3 } & & Swelling value \\
\cline { 3 - 3 } & & Dimension structures \\
\cline { 3 - 3 } & & Loading \\
\hline \multirow{2}{*}{2.} & \multirow{2}{*}{ Output } & Crack pattern \\
\cline { 3 - 3 } & & Structure Design \\
\hline
\end{tabular}

The existing input data are then input into the ATENA 3D software for further analysis to obtain output data in the form of deflections, crack patterns, and structural model drawings. Figure. 2 to Figure. 4 below is an image of the modeling along with the load placement that has been inputted into the ATENA software:

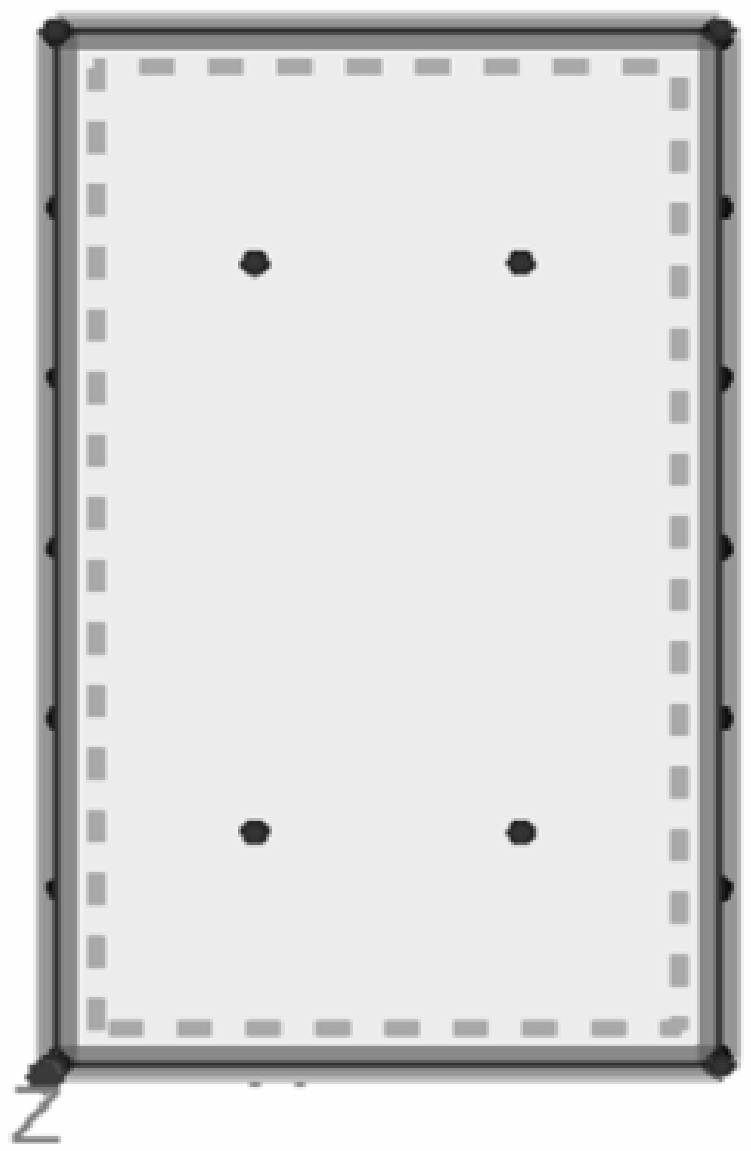

Figure 2. Centre Loading Modelling 


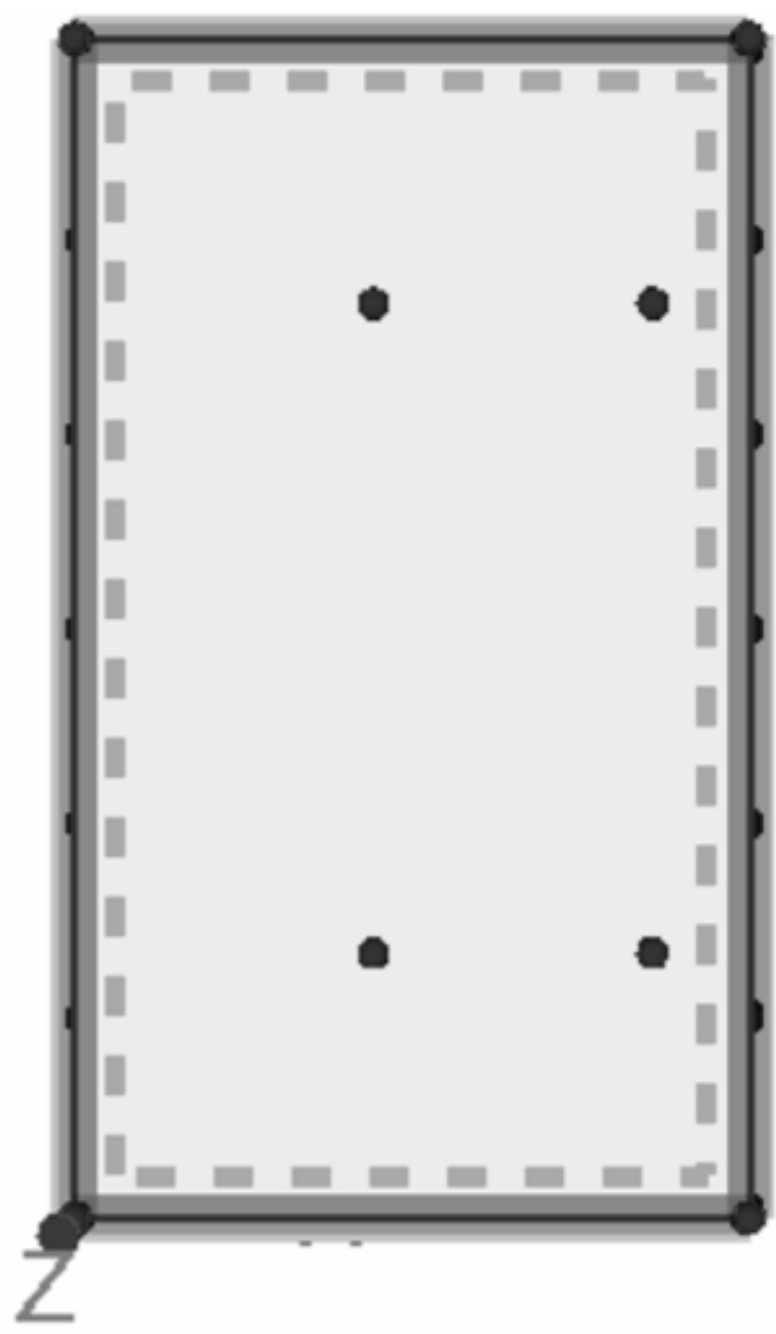

Figure 3. Edge Loading Modelling

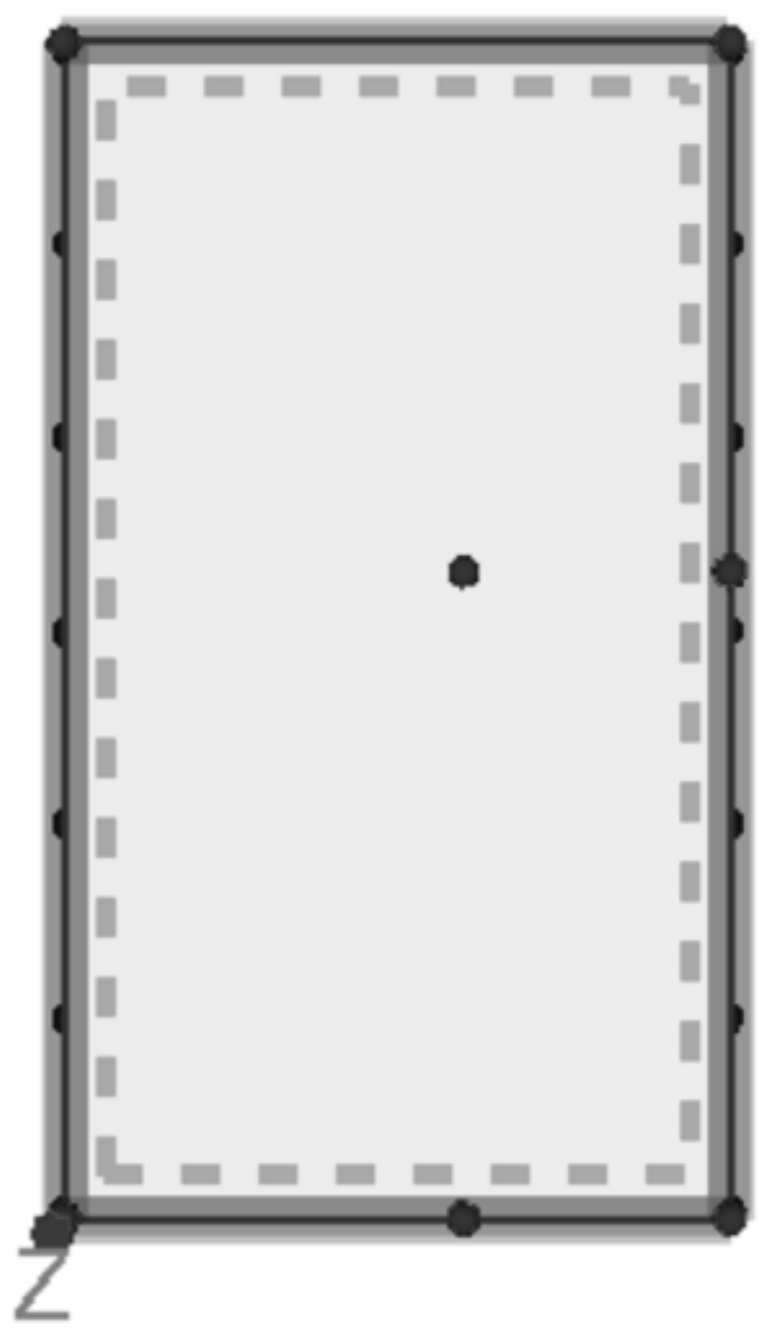

Figure 4. Corner Loading Modelling 


\section{Results and Discussion}

The soil properties test was carried out in the soil mechanics laboratory before being analyzed on the ATENA software. This program can be used to predict crack patterns that occur in structures. The loading is done by applying a point load to the slab, the load is evenly distributed over the concrete surface area. The loading is carried out with a fixed vehicle load, where iterations are carried out using the Newton-Rapson method with an initial load step of 50 load steps with a total of 20 iterations. The results of the soil properties test as presented in Table 3.

Table 3. Data on soil properties test results

\begin{tabular}{|c|c|c|c|c|}
\hline No. & \multicolumn{2}{|c|}{ Test Type } & Result & Information \\
\hline \multirow{4}{*}{1.} & \multirow{4}{*}{$\begin{array}{c}\text { Grain Size } \\
\text { Analysis }\end{array}$} & Gravel (\%) & 0.00 & \multirow{9}{*}{ Organic Clay } \\
\hline & & Sand $(\%)$ & 28.65 & \\
\hline & & Silt (\%) & 57.62 & \\
\hline & & Clay (\%) & 13.72 & \\
\hline 2. & $\begin{array}{c}\text { Specific } \\
\text { Gravity }(\%)\end{array}$ & \multicolumn{2}{|c|}{2,61} & \\
\hline \multirow{4}{*}{3.} & \multirow{4}{*}{$\begin{array}{l}\text { Atterberg } \\
\text { Limit }\end{array}$} & $\mathrm{LL}(\%)$ & 69.56 & \\
\hline & & PL (\%) & 36.00 & \\
\hline & & IP (\%) & 33.56 & \\
\hline & & SL (\%) & 5.46 & \\
\hline
\end{tabular}

Soil properties that have been tested for soil properties are then tested for swelling and swelling pressure with an oedometer test. The results of the oedometer test as presented in Table 4

Table 4. Data swelling and swelling pressure

\begin{tabular}{|c|c|}
\hline \multicolumn{2}{|c|}{ Data } \\
\hline Initial water Content & $2.07 \%$ \\
\hline Final Water content & $45.77 \%$ \\
\hline Percentage of Swelling & $7.50 \%$ \\
\hline Swelling Pressure & $37 \mathrm{kPa}$ \\
\hline
\end{tabular}

The data are then used as input data in ATENA for further analysis of the deflection that occurs. The following is the result of the modeling when all data have been input in ATENA as presented in Figure 5, Figure 6 and Figure 7 for center load, edge load and corner load, respectively.

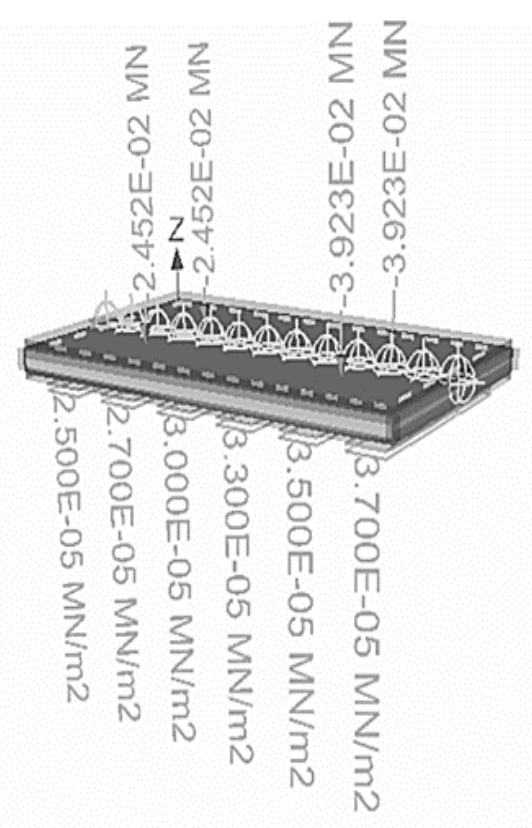

Figure 5. Modeling Results after Data is Input (Centre Loading)

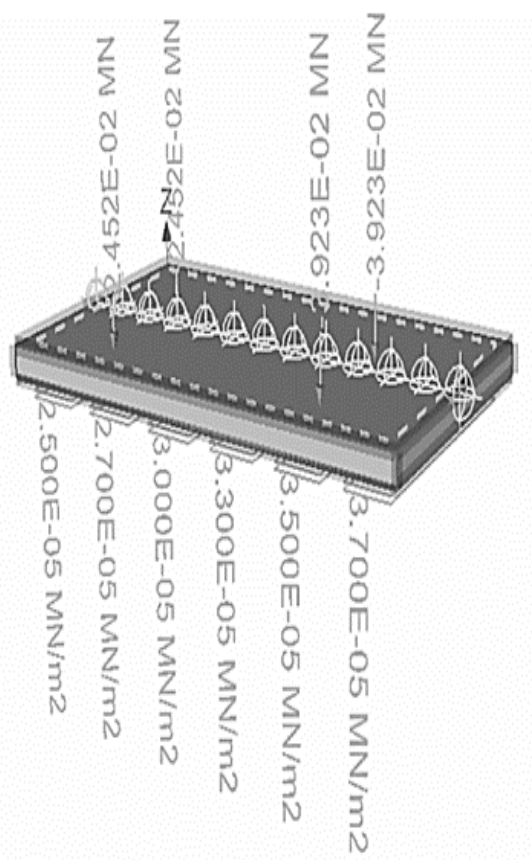

Figure 6. Modeling Results after Data is Input (Edge Loading) 


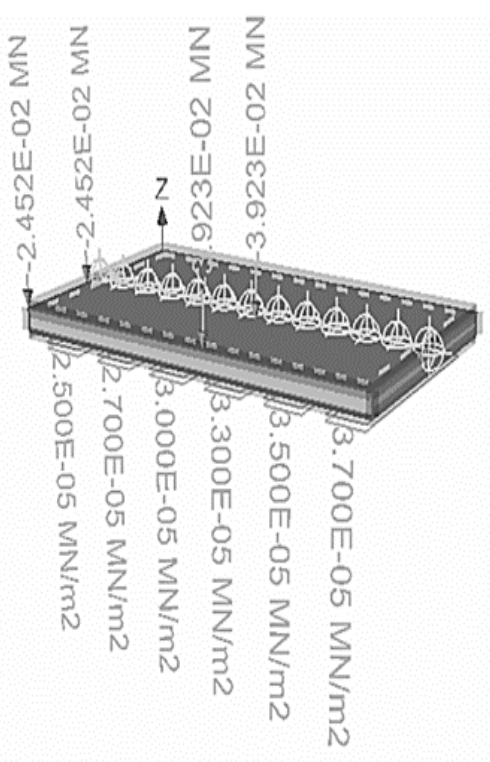

Figure 7. Modeling Results after Data is Input (Corner Loading)

The results of the analysis of rigid pavement crack patterns with transverse reinforcement using the ATENA program are explained in the following sub chapter.

\subsection{Edge Loading}

The picture of the crack pattern of a rigid pavement model with transverse reinforcement on the bearings on the edge is presented in Figure 8 and Figure 9.

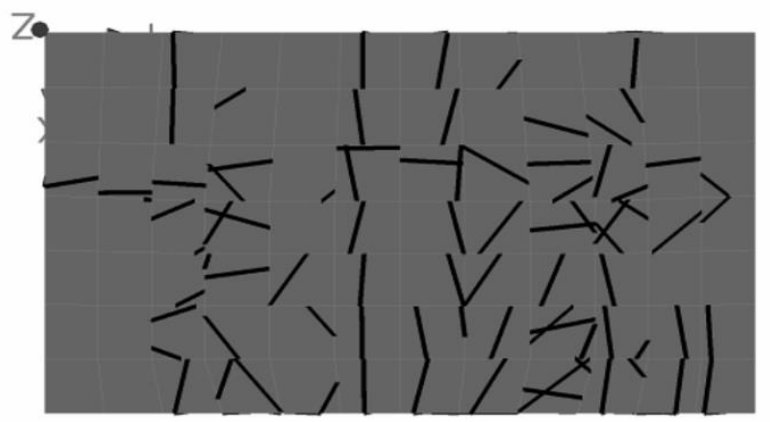

Figure 8. Crack pattern using the Athena program on edge loading without swelling pressure.

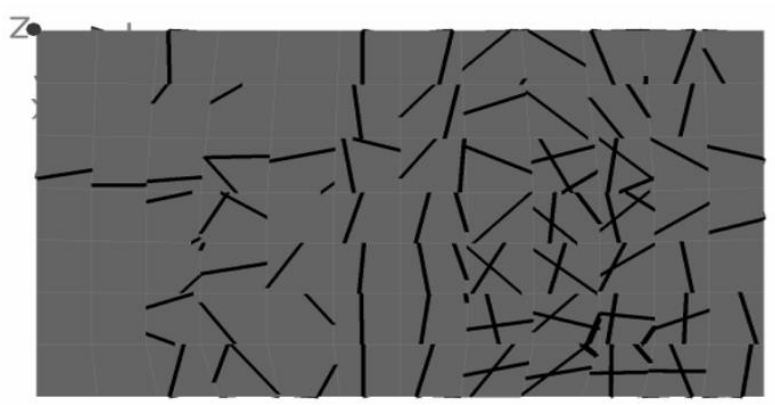

Figure 9. Crack pattern using the Atena program on edge loading due to swelling pressure.
The pattern of cracks that occur in rigid pavements with transverse reinforcement without swelling pressure forces edge loading is $67.86 \%$ (cracks in 57 elements out of 84 elements) and in rigid pavements with transverse reinforcement due to swelling pressure forces edge loading is $71.43 \%$ (cracked at 60 elements out of 84 elements).

\subsection{Centre Loading}

The image of the crack pattern of the Middle pavement model with transverse reinforcement on the center load placement is presented in Figure 10 and Figure 11.

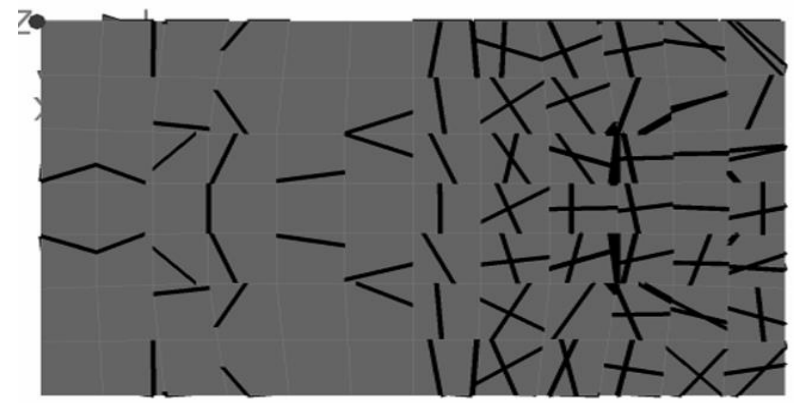

Figure 10. Crack pattern using the Atena program at the center of the load without swelling pressure.

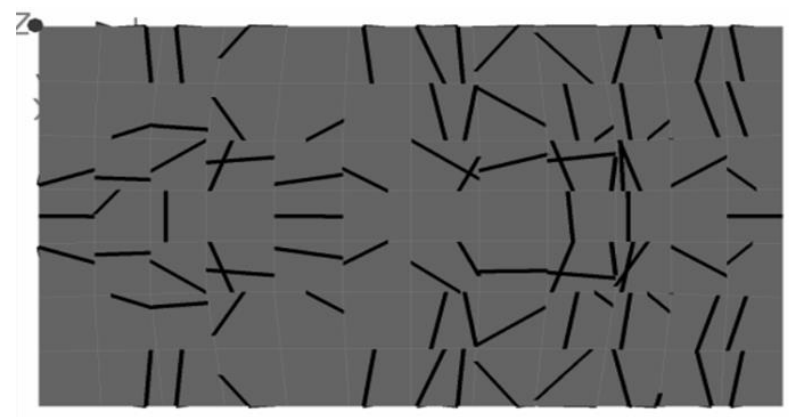

Figure 11. Crack pattern using the Atena program in the middle load due to swelling pressure.

The pattern of cracks that occur in rigid pavements with transverse reinforcement without swelling pressure forces edge loading is $76.86 \%$ (cracks in 64 elements out of 84 elements) and in rigid pavements with transverse reinforcement due to swelling pressure forces edge loading is $84.43 \%$ (cracked at 71 elements out of 84 elements).

\subsection{Corner Loading}

The figure of the crack pattern of the rigid pavement model with transverse reinforcement on the loading placement at the corner is presented in Figure 12 and Figure 13. 


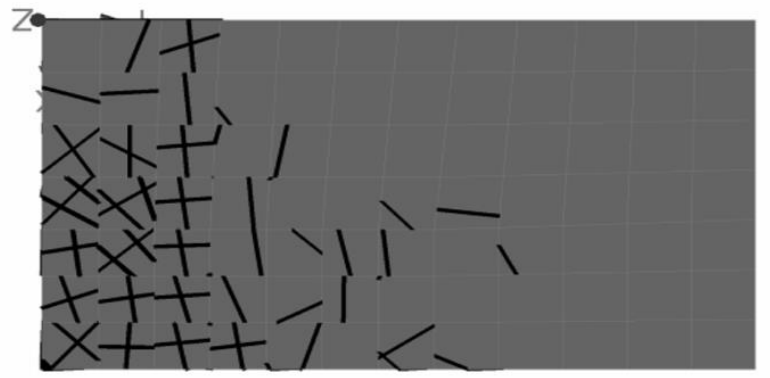

Figure 12. Crack pattern using the Athena program on corner loading without swelling pressure.

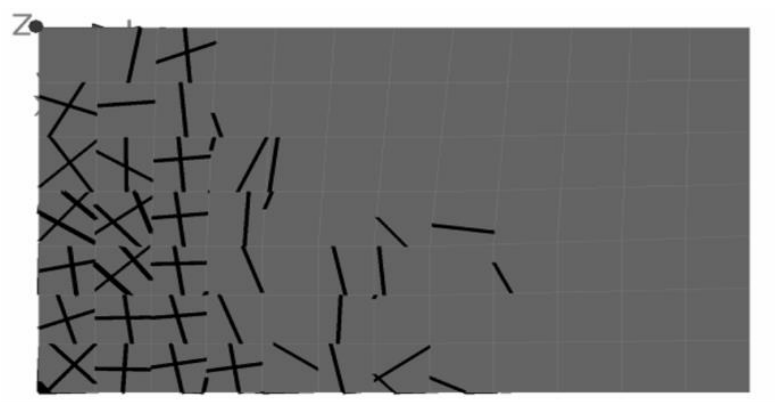

Figure 13. Crack pattern using the Atena program on corner loading due to swelling pressure forces

The pattern of cracks that occur in rigid pavements with transverse reinforcement without swelling pressure force of middle loading is $38.10 \%$ (Cracks in 32 elements of 84 elements) and in rigid pavements with transverse reinforcement due to swelling pressure forces of middle loading of $41.67 \%$ (Cracks at 35 elements out of 84 elements).

A recapitulation of the image of the crack pattern that occurs in rigid pavement with reinforcement is presented in Table 5.

Table 5. Data on soil properties test results.

\begin{tabular}{|c|c|c|c|}
\hline \multirow{2}{*}{$\begin{array}{c}\text { Types of Rigid } \\
\text { Pavement } \\
\text { Loading }\end{array}$} & $\begin{array}{c}|c| \\
\text { No swelling } \\
\text { pressure }\end{array}$ & $\begin{array}{c}\text { Wrack (\%) } \\
\text { Wwelling } \\
\text { pressure }\end{array}$ & Difference \\
\hline Load Edge & $67.86 \%$ & $71.43 \%$ & $3.50 \%$ \\
\hline Load Central & $76.19 \%$ & $84.52 \%$ & $8.33 \%$ \\
\hline Load Corner & $38.10 \%$ & $41.67 \%$ & $3.57 \%$ \\
\hline
\end{tabular}

Table 5 shows that for each type of loading on rigid pavement, there is a difference between loading without swelling pressure forces and loading due to swelling pressure forces. Previous research said that the location of the loading had a significant effect on the cracks that occurred [12]. Rigid pavement edge loading with swelling pressure force increased cracking by $3.5 \%$ compared to without swelling pressure force, center loading of rigid pavement with swelling pressure increased cracking by $8.33 \%$ compared to without swelling pressure force, and loading Rigid pavement corners with swelling pressure have an increases in cracks of $3.57 \%$ compared to those without swelling pressure forces.

These data indicate that the cracks produced by loading on rigid pavements due to swelling pressure forces are greater than the loading of rigid pavements without swelling pressure forces. This is due to the vertical upward force of the soil, one of which is caused by the presence of water that enters the ground when it rains, resulting in the development of the soil which causes the concrete slab to be lifted and added to the load from the traffic above it which causes more damage severe, this fact is quite similar to the research conducted by Mehta et al [13]. Swelling means that the volume of the soil becomes larger than the previous volume due to the increase in water content as stated by Das[14], so that the swelling increases the potential damage to the rigid pavement. The results are similar to what happened in the experimental evaluation of lateral swelling pressure of expansive soil fill behind a retaining wall. It shows that swelling pressure on the soil can lead to failure of retaining walls [15]. Another study provides a solution to the damage of rigid pavement by overlaying it on rigid pavement using the flexible pavement. However, this study did not specifically mention the type of damage that occurred [16].

\section{Conclusions}

The results of the analysis from the ATENA software program show that every loading test on rigid pavement due to swelling pressure forces cracks greater than loading without swelling pressure forces.

Edge loading shows that cracks due to swelling pressure are 3.5\% higher than those without swelling pressure. Middle loading shows cracks due to swelling pressure force $8.33 \%$ greater than without swelling pressure force. Corner loading shows that cracks due to swelling pressure are $3.57 \%$ higher than without swelling pressure. This is due to the vertical force above the ground caused by water entering the soil when it rains, resulting in soil development which causes the concrete slab to lift. Then there is the load from the traffic on it which causes more damage.

The analysis in this study uses software that is still rarely used in research, namely the ATENA software. ATENA software can be used to analyze the damage to rigid pavement structures so that it can be used as a prediction and reference for carrying out maintenance and rehabilitation before serious damage occurs so that the service life of the road can be achieved accordingly.

It is necessary to investigate the structural laboratory prototype of the pavement model according to real conditions in further research so that verification data are obtained for research using the ATENA software program. 


\section{Acknowledgements}

We would like to thank our supervisors who have helped in writing this journal. Thank you for all the input and suggestions so that this journal can be published.

\section{REFERENCES}

[1] Korochkin, A., "Impact of rigid pavements with the asphalt-concrete wearing course on road performance and traffic safety", Transportation Research Procedia. Elsevier B.V., 36, pp. 315-319, 2018. DOI: 10.1016/j.trpro.2018.12.091.

[2] Karaseran, A. J., Sompie, O. B., \& Balamba, S., "Pengaruh bahan campuran arang tempurung terhadap Konsolidasi sekunder pada lempung ekspansif”. Jurnal Sipil Statik, 3(8), 2015.

[3] Deshmukh, A., Rabbani, A. and Dhapekar, N. K., "Study of rigid pavements - Review", International Journal of Civil Engineering and Technology, 8(6), pp. 147-152, 2017.

[4] Mulia, T., “Analisis Desain Perkerasan Kaku Pada Tanah Ekspansif" (Studi Kasus: Ruas Jalan Kecamatan Paron Kabupaten Ngawi) (Doctoral dissertation), Universitas Brawijaya, 2012.

[5] Dodiek Wirya Ardana, M. and Agus Ariawan, I. M., "The significance of concrete slab flexural strength inference variation based on its compression strength characteristics in apron pavement analysis and design", MATEC Web of Conferences, 276, p. 01038, 2019. DOI: 10.1051/mateccon $\mathrm{f} / 201927601038$.

[6] Darwis, M. S., "Dasar-Dasar Teknik Perbaikan Tanah". Pustaka AQ, Agustus, 240, 2017.

[7] Rasol, M. A. et al., "GPR laboratory tests and numerical models to characterize cracks in cement concrete specimens, exemplifying damage in rigid pavement", Measurement:
Journal of the International Measurement Confederation. Elsevier Ltd, 158, p. 107662, 2020. DOI: 10.1016/j.measurement.2020, 107662.

[8] Hilyanto, R. R., Setiawan, B., "Simulasi Perilaku Pelat Beton Sebagai Perkerasan Kaku Di Atas Tanah Subgradesaradan Menggunakan Metode Elemen Hingga", Matriks Teknik Sipil, (September), pp. 296-303, 2013.

[9] Cervenka, J., Jendele, L., \& Smilauer, V. (2014). “ATENA simulation of crack propagation in CONCRACK benchmark", European journal of environmental and civil engineering, 18(7), 828-844.

[10] Ersoz, A. B., Pekcan, O. and Teke, T., "Crack identification for rigid pavements using unmanned aerial vehicles", IOP Conference Series: Materials Science and Engineering, 236(1), 2017. DOI: 10.1088/1757-899X/236/1/012101.

[11] Hardiyatmo, H. C., "Perancangan Sistem Cakar Ayam Modifikasi untuk Perkerasan Jalan Raya" Edisi Kedua,Yogyakarta: Gadjah Mada University Press, 2014.

[12] Yasir, F., Surjandari, N. S. and Purwana, Y. M., “Analisis Lendutan Perkerasan Kaku Pada Pembebanan Sudut Dengan Metode Elemen Hingga”, Jurnal Muara Sains, Teknologi, Kedokteran dan Ilmu Kesehatan, 1(1), pp. 150156, 2017. DOI: 10.24912/jmstkik.v1i1.426.

[13] Mehta, Y., Cleary, D. and Ali, A. W., "Field cracking performance of airfield rigid pavements", Journal of Traffic and Transportation Engineering (English Edition). Elsevier Ltd, 4(4), pp.Moghal A. A. B., Dafalla, 2017.

[14] Das, BM., "Fundamental of Soil Dynamics", Elsevier Pub., NewYork, 1983.

[15] Zhengnan Liuet al. Journal of Materials in Civil Engineering, 32, 2, 12, 2019.

[16] Wibowo, Setyawan, A. and Prasetyo, H. (2020) 'ANALISIS PELAT PERKERASAN KAKU RUAS JALAN SONGGORUNGGI-', Jurnal Matriks Teknik Sipil, 8(4), pp. 407-414. doi: https://doi.org/10.20961/mateksi.v 8 i1. 